\title{
Zeolit Katkısının Antibakteriyel ve Kendi Kendini Temizleyen Harç Özeliklerine Etkisi
}

\author{
Murat GÜLDAȘ ${ }^{1}$, Mehmet CANBAZ ${ }^{2 *}$, Mehmet ORHAN ${ }^{3}$ \\ ${ }^{1}$ Eskişehir Osmangazi Üniversitesi, Fen Bilimleri Enstitüsü, İnşaat Mühendisliği ABD, Eskişehir, Türkiye \\ ${ }^{2}$ Eskişehir Osmangazi Üniversitesi, Mühendislik Mimarlık Fakültesi, İnşaat Mühendisliği Bölümü, Eskişehir, \\ Türkiye \\ ${ }^{3}$ Uludağ Üniversitesi, Mühendislik Fakültesi, Tekstil Mühendisliği Bölümü, Bursa, Türkiye \\ (ORCID: 0000-0001-5979-6152) (ORCID: 0000-0002-0175-6155) (ORCID: 0000-0001-8043-4148)
}

\begin{abstract}
$\ddot{O} z$
İnşaat sektöründe son yıllarda yapılan çalışmalarda yapıları sağlık açısından daha güvenli hale getirmek için yapı malzemelerine antibakteriyel özellik kazandırılması ve dış mekândaki korunmasız olarak dış etkilere maruz kalan yapı malzemelerine 1 şı etkisiyle kendi kendini temizleme yeteneği kazandırılması hedeflenmiştir. Bu çalışmada beyaz ve gri çimento ile üretilen harçlara antibakteriyel özellik kazandırmak amacıyla gümüş iyonları içerikli antibakteriyel toz ve antibakteriyel özellikli sıvı mergal, kendi kendini temizleme özelliği kazandırmak için anataz ve rutil fazında titanyum dioksit tozu, iyon değişimini kolaylaştırmak için zeolit farklı oranlarda ilave edilmiştir. Karışımlardan alınan numuneler üzerinde birim ağırlık, ultrases geçiş hızı, eğilme ve basınç dayanımı deneyleri yapılmıştır. İlave edilen katkıların fiziksel ve mekanik özeliklere etkileri belirlenmiştir. İtalyan standartlarına göre kendi kendine temizleme deneyleri ve Amerikan standartlarına göre antibakteriyel etkinlik deneyleri yapılmıştır. Yapılan deneyler sonucunda ilave edilen katkıların harçların fiziksel ve mekanik özeliklerine olumsuz etkileri olmadığı, titanyum dioksit tozunun kendi kendini temizlemede etkili olduğu ve antibakteriyel katkıların ise bakterilere karşı etkili bir şekilde kullanılabileceği görülmüştür.
\end{abstract}

Anahtar kelimeler: Kendi kendini temizleme, Fotokataliz, Antibakteriyel Etkinlik, Zeolit, Harç.

\section{Effect of Zeolite Additives on the Antibacterial and Self-Cleaning Mortar Properties}

\begin{abstract}
In recent studies in the construction sector, it is aimed to give antibacterial properties to building materials in order to make the buildings safer in terms of health and to give the building materials exposed to external effects unprotected outdoors with the ability to self-clean with the effect of light. In this study, an antibacterial powder containing silver ions and liquid Mergal with antibacterial properties, titanium dioxide powder in anatase and rutile phase to give it selfcleaning properties, and zeolite in different proportions to facilitate ion exchange were added to the mortars produced with white and gray cement. Unit weight, ultrasonic pulse velocity, bending, and compressive strength tests were performed on the specimens taken from the mixtures. The effects of added additives on physical and mechanical properties were determined. Self-cleaning tests according to Italian standards and antibacterial activity determination tests were carried out according to American standards. As a result of the experiments, it has been observed that the additives added do not have negative effects on the physical and mechanical properties of the mortars, titanium dioxide powder is effective in self-cleaning and antibacterial additives can be used effectively against bacteria.
\end{abstract}

Keywords: Self-cleaning, Photocatalysis, Antibacterial Activity, Zeolite, Mortar.

\section{Giriş}

İnsanın dışında olan her şey olarak tanımlayabileceğimiz içinde bulunduğumuz çevre, hastalıklara neden olan en önemli nedenlerin başındaki mikroorganizmalar ile her an temasta olduğumuz ortamdır [1]. Günümüzde hayat tarzının değişmesi ve bireylerin zamanlarının büyük bir kısmını ev dışında

"Sorumlu yazar: mcanbaz@ogu.edu.tr

Geliş Tarihi: 04.02.2021, Kabul Tarihi: 09.07.2021. 
geçirmeleri, değişen yaşam ve beslenme alışkanlıkları ve ulaşım olanakları, uluslararası seyahatler gibi faktörler, mikroorganizmaların, toplu yaşam bölgelerinde kolaylıkla bireyden bireye aktarılmasına ve bulaşıcı hastalıkların artmasına sebep olduğundan yaşanılan ve çalışılan ortamlarda kullanılan ürünlerde hijyenin sağlanması, hastalık oluşturabilecek mikroorganizmalardan arındırılması giderek önemli hale gelmektedir [2]. Hijyen gereken ortamlarda her ne kadar temiz tutulmaya çalış1lsa da bir süre sonra istenmeyen mikroorganizmalar tekrar çoğalmakta, insan sağlığını tekrar tehdit etmektedir. Mikroorganizmaların tekrar çoğalmasını engellemek için betonun içyapısında değişikliğe gitme ve bu sayede çeşitli endüstrilerde hâlihazırda elde edilmiş olan antibakteriyel özellikleri betona kazandırma fikri ortaya çıkmıştır. Son yıllarda bu amaca yönelik olarak fotokatalitik oksidasyon, gümüş ve bazı ağır metal içeren antimikrobiyal sistemler ile ilgili çalışmalar yürütülmekte olup, başarılı sonuçlar elde edilmiştir. Fotokatalitik etkiye sahip malzemelerin başında anataz formunda titanyum dioksit $\left(\mathrm{TiO}_{2}\right)$ gelmektedir. Fotokatalitik sistemler, ultraviyoleye (UV) maruz bırakıldığında aktif oksijen oluşumuna yol açmaktadır. Aktif oksijen, fotokatalitik malzemenin bulunduğu bölgede organik maddelerin oksitlenmesi, bakterilerin ölmesi, organik lekelerin temizlenmesi ve havadaki rahatsız edici kokuların giderilmesi gibi özelliklere sahiptir. Bu malzemelerin en etkili olduğu kullanım alanları UV ışınımını sağlayan fotokatalitik kaplamaların hava temizleme sistemleridir. $\mathrm{Ag}^{+1}, \mathrm{Cu}^{+2}, \mathrm{Zn}^{+2}$ bilindiği üzere gibi bazı metal iyonları bakterilerin metabolizmalarına girmekte ve enzimlerini etkisiz hale getirmektedirler. Diğer bazı sistemler ise hidrojen peroksit oluşturarak bakterilerin ölmesine sebep olmaktadır. Ancak bu mekanizmalarda açıklanması gereken bazı hususlar bulunmaktadır. Doğal veya insan etkisiyle ortaya çıkan kirleticiler, yapıların ve yapı malzemelerinin Şekil 1'de görüldüğü gibi dış görünümlerini olumsuz yönde etkilemektedir [3].
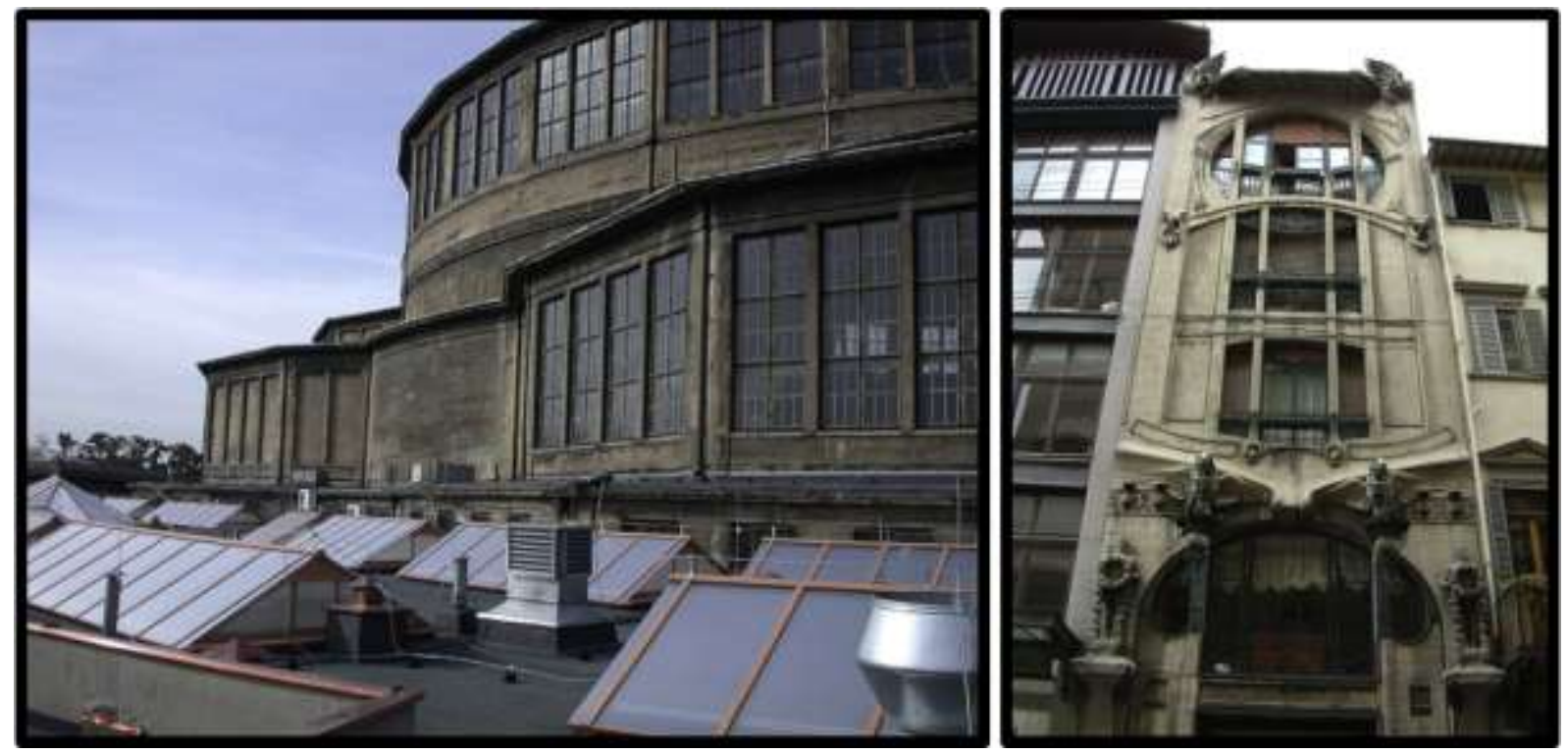

Şekil 1. Doğal ve insan etkisi ile diş cephelerde oluşan kirlenmeler

Çimento esaslı kompozit malzemeler daha üretilirken malzemelerin içerisine $\mathrm{TiO}_{2}$ ilave edilerek söz konusu elemanların fotokatalitik özellik kazanması ve yüzey kirleticilerinden arınmasını sağlayan çalışmalar bulunmaktadır [4]. Fotokatalitik özelliğe sahip kendi kendini temizleme yeteneğine sahip titanyum dioksit içeren beton, harç, derz ve çimentoların bu özellikleri sayesinde bakım masrafları azalmakta ve büyük bir iş gücü ve zaman kaybı önlenebilmektedir. Fotokatalizmin kullanım alanları Fujishima ve Honda'nın 1972 'de yaptığ 1 çalışmada ortaya koyduğu $\mathrm{TiO}_{2}$ ile suyun ayrışması ve bu sayede kendi kendini temizleme fikrini ortaya aymasından sonra dikkatleri bu yöne çekmiş ve bu fikir oldukça geliştirilmiştir. Fujishima ve arkadaşları UV 1şı etkisinde $\mathrm{TiO}_{2}$ ile kaplanmış yüzeyin ıslanmasındaki belirgin değişikliği fark ederek yüzeyi çeşitli kirleticilerin yapışmasından koruyabildiğini keşfettiler. UV ışı altında yüzeye gelen suyun temas açısının $\mathrm{TiO}_{2}$ yüzeyine yerleşme eğiliminden dolayı azalması neticesinde yüzey bu aşamada hidrofobisite adı verilen su geçirimsiz hale gelir. Bu hidrofibisite oksidatif özelliklerin birleşmesi ile $\mathrm{TiO}_{2}$ uygulanmış yüzeylerin herhangi bir bakım gerekmeksizin güneș 1şığı altında uzun süre temiz kalmasını sağlayabilmektedir. Bu özelliğe 
"kendi kendini temizleme özelliği” adı verilmekte olup, evlerde, elektrikli aletlerde, yollarda, tarımsal uygulamalarda, su arıtma teknolojilerinde, tekstilde ve tıpta kullanılmaktadır [5]. Nanoteknoloji ile üretilmiş betonlar kavramının içerisinde kullanılan nanoteknoloji içerisinde betona üretim aşamasında eklenen ve nanoparçacık olarak tanımlanabilecek Titanyum dioksit ve Çinko oksit bulunmasındandır. Geniş bir kullanım alanına sahip bu parçacıklar yüzeylere tabaka halinde uygulandıklarında fotokataliz ile yüzey aktivitesini arttırırlar. $\mathrm{TiO}_{2}$ fotokatalizi UV ışı̆̆ı altında boşluk $\left(\mathrm{h}^{+}\right)$ve elektron çifti $\left(\mathrm{e}^{-}\right)$ yüzeydeki $\mathrm{H}_{2} \mathrm{O}$ ve $\mathrm{O}_{2}$ ile reaksiyona girer. Reaksiyon sonucu hidroksit iyonu $\left(\mathrm{OH}^{-}\right)$ve süperoksit iyonu $\left(\mathrm{O}^{-2}\right)$ oluşur [6]. Aynı zamanda $\mathrm{TiO}_{2}$ fotokatalizi ile hidrokarbonların $\mathrm{CO}_{2}$ ve $\mathrm{H}_{2} \mathrm{O}$ ayrışması da gerçekleşir ve bu oluşum kendi kendini temizleyen yüzeyler ile ilgili çalışmalarda ele alınan temel reaksiyondur. $\mathrm{Bu}$ zincir reaksiyonlar ile $\mathrm{TiO}_{2}$ uygulanmış yüzeylerin maruz kaldıkları kirleticilerin yapı taşlarına ayrışması ve bu sayede temiz kalması sağlanmaktadır [7]. Şekil 2'de fotokatalik çimento ve beton uygulamaları görülmektedir [8].
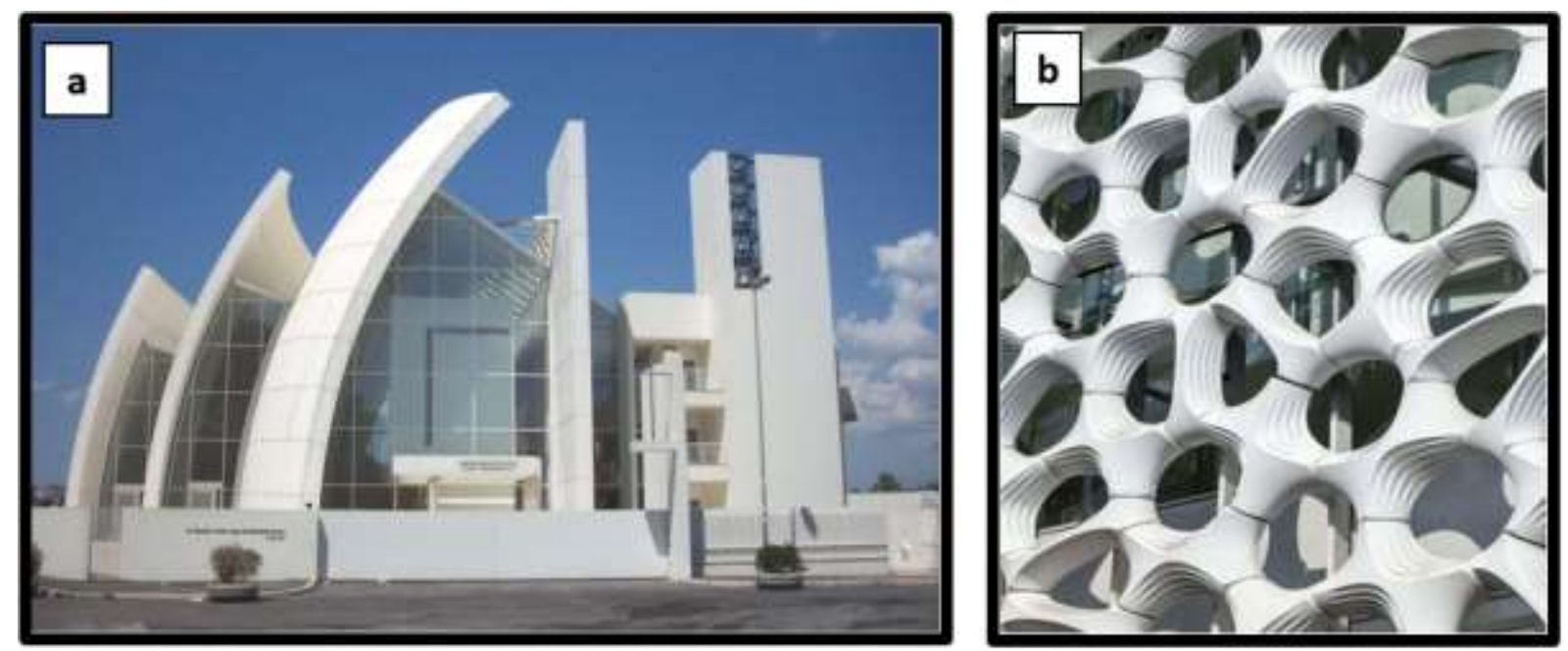

Şekil 2. Fotokatalitik beton ile üretilen Jübile Kilisesi (a), Manuel Gea Gonzalez Hastanesi (b)

Özellikle sanayi devriminden bugüne kadar geçen zamanda her geçen yıl daha da egzoz gazları, enerji santralleri, fabrikalar, petrol rafinerileri gibi kullanım alanlarında artan hidrokarbon tüketimi sonucu kontrollü ya da serbest bir şekilde doğaya salınan gazlar havayı ve çevreyi kirletmektedir. Çevresel kirlenmenin yapı ve malzemelerine olan olumsuz etkisi malzemenin görüntüsü ve yapısına etkiyerek ona zarar vermekte, görsel kirliliğin yanı sıra kullanım ömürlerini de azaltmaktadır. $\mathrm{Bu}$ nedenle günümüzde üzerine gelen organik bileşik bazlı kirleticileri parçalayarak görüntü ve yapısını koruyan $\mathrm{TiO}_{2}$ katkılı yapı malzemelerinin üretimi gittikçe önemli hale gelmiştir. Yine günümüzde hijyen gerektiren ortamlara duyulan ihtiyacın artması ve sürekli yapay hijyen sağlamanın maliyetli ve düşük etkili olması sebebiyle yapılarda iç mekanlarda kullanılan yapı malzemelerinde anataz yapıda $\mathrm{TiO}_{2}$ tozu, zeolit, gümüş iyonları içerikli antimikrobiyal toz ve antimikrobiyal özellikli sıvı mergal farklı oranlarda ilavelerle numuneler üretilerek söz konusu yapı malzemelerinin antibakteriyel özelliklerinin geliştirilmesi amaçlanmıştır. Burada zeolitler iyon değişimi ve adsorpsiyon yeteneklerinin yanı sıra katalizör olarak da kullanılabilmeleri [9] nedeni ile kullanılmıştır. Literatürde antibakteriyel özellik gösteren bu katkı maddesi kullanılarak antibakteriyel özellik kazandırma çalışmaları tekstilde [10, 11], film kaplama şeklinde ve temizleyici kimyasallarda yapılmışsa da doğrudan inşaat sektöründeki yapı elemanlarında yapılmamıştır. Günümüzde dünyada başta İtalya ve Japonya olmak üzere birçok gelişmiş ülkede fotokatalitik özelliğe sahip yapı malzemesi kullanılmaktadır [12]. Kendi kendini temizleyen betonlar beton yollar, parke taşları, kaldırımlar ve dış cephe kaplamaları gibi alanlarda uygulanmakta ve olumlu sonuçlar alınmaktadır [13]. Uygulama sayısı dünyada her geçen gün artmakta olup, henüz Türkiye' de bu alanda bir uygulama mevcut değildir. Bu çalışmada dış etkilerin içyapıya eklenen katkılar sayesinde bertaraf edilmesi ve yap1 elemanına etkisinin minimumda kalmasının yanı sıra, $\mathrm{TiO}_{2}$ katkısının çeşitli iyon takviyeleri ile antibakteriyel özellik göstermesinden hareketle bu çalışmada kendi kendini temizleyen ve ilk imalat edildiklerindeki yapısal ve fiziksel özelliklerini koruyan yap1 malzemelerinin üretiminin sağlanabileceği incelenmiştir. Aynı zamanda da $\mathrm{TiO}_{2}$ beraberinde kullanılan zeolit, gümüş iyonları içerikli antimikrobiyal toz ve anti-mikrobiyal özellikli sıvı mergal sayesinde 
antibakteriyel özellik gösteren yapı elemanlarının üretimi ve insan sağlığını tehdit eden bakterilerin üreme ortamlarının ortadan kaldırılarak steril ortamlar oluşturulması amaçlanmıştır. Bu amaçla çimento miktarının $\% 0, \% 1, \% 3, \% 5$ oranında $\mathrm{TiO}_{2}$ kullanılarak harçlar numuneler üretilmiştir. Sertleşmiş özelliklerinin belirlenmesi için birim ağırlık, ultrases geçiş hızı ve basınç dayanımı deneyleri yapılmıştır. $\mathrm{Bu}$ numuneler üzerinde $\mathrm{TiO}_{2}$ ile kendi kendini temizleme özellikleri ve $\mathrm{Ag}^{+}$iyonu katkılandırılarak antibakteriyel özellikleri incelenmiştir.

\section{Materyal ve Metot}

Kendi kendini temizleyen ve anti bakteriyel harç üretiminde çimento, agregalar, su, zeolit, antibakteriyel katkı ve $\mathrm{TiO}_{2}$ kullanılmıştır. Deneylerde Eskişehir Çimsa Çimento Fabrikasında üretilen ve TS EN 1971: 2002 standartlarında CEM I 42,5 R gri çimento ve CEM I 52,5 R beyaz çimento kullanılmıştır. Bu çimentolara ait kimyasal ve mekanik özellikler Tablo 1'de verilmiştir.

Tablo 1. Kullanılan çimentonun kimyasal, fiziksel ve mekanik özelikleri

\begin{tabular}{|c|c|c|c|c|c|}
\hline$\overline{\text { Kimyasal analiz, \% }}$ & $\begin{array}{c}\text { GRİ } \\
\text { CEM I }\end{array}$ & $\begin{array}{c}\text { BEYAZ } \\
\text { CEM I }\end{array}$ & Fiziksel Özelikler & $\begin{array}{c}\text { GRİ } \\
\text { CEM I }\end{array}$ & $\begin{array}{c}\text { BEYAZ } \\
\text { CEM I }\end{array}$ \\
\hline$\overline{\mathrm{SiO}_{2}}$ & 18.9 & 21.6 & Yoğunluk, kg/dm ${ }^{3}$ & 3.08 & 3.06 \\
\hline $\mathrm{Al}_{2} \mathrm{O}_{3}$ & 5.15 & 4.05 & Özgül Yüzey, $\mathrm{cm}^{2} / \mathrm{g}$ & 3370 & 4600 \\
\hline $\mathrm{Fe}_{2} \mathrm{O}_{3}$ & 3.36 & 0.26 & Basınç Dayanımı, MPa & & \\
\hline $\mathrm{CaO}$ & 63.59 & 65.7 & 2 gün & 11.9 & 37 \\
\hline $\mathrm{MgO}$ & 1.57 & 1.3 & 7 gün & 26.7 & 50 \\
\hline $\mathrm{SO}_{3}$ & 2.65 & 3.3 & 28 gün & 42.8 & 60 \\
\hline LOI & 3.59 & 3.2 & & & \\
\hline
\end{tabular}

Karma suyu olarak Eskişehir normal şebeke suyu kullanılmıştır. Tablo 2'de üretimde kullanılan şebeke suyunun kimyasal analiz özellikleri verilmiştir.

Tablo 2. Deneydeki beton karma suyunun özellikleri

\begin{tabular}{lcclcc}
\hline Alüminyum & $(\mathrm{mg} / \mathrm{l})$ & 0,06 & pH değeri & & 8,00 \\
Nitrat & $(\mathrm{mg} / \mathrm{l})$ & 8,80 & İletkenlik & $(\mu \mathrm{g} / \mathrm{l})$ & 568 \\
Nitrit & $(\mathrm{mg} / \mathrm{l})$ & 0,005 & Toplam organik karbon & $(\mathrm{mg} / \mathrm{l})$ & 23,80 \\
Amonyum & $(\mathrm{mg} / \mathrm{l})$ & 0,07 & Sertlik & $\left(\mathrm{fr}^{\circ}\right)$ & 31,43 \\
Sülfat & $(\mathrm{mg} / \mathrm{l})$ & 78 & Toplam çözünmüş madde & & 341 \\
Demir & $(\mathrm{mg} / \mathrm{l})$ & 0,005 & Arsenik & $(\mu \mathrm{g} / \mathrm{l})$ & 3,57 \\
\hline
\end{tabular}

Zeolit olarak Manisa-Gördes yöresinden elde edilen doğal zeolit kullanılmıştır. Bu zeolite ait kimyasal ve mekanik özellikler Tablo 3'te verilmiştir.

Tablo 3. Kullanılan zeolitin kimyasal ve fiziksel özelikleri

\begin{tabular}{|c|c|c|c|}
\hline \multicolumn{2}{|c|}{ Mineral içeriği, \% } & \multicolumn{2}{|c|}{ Fiziksel Özelikler } \\
\hline Klinoptilolit & $90-95$ & Görünüm & Fildişi beyazı \\
\hline \multicolumn{2}{|c|}{ Kimyasal analiz, \% } & Porozite, $\%$ & $45-50$ \\
\hline $\mathrm{SiO}_{2}$ & $65-72$ & Sertlik, Mohs & $2-3$ \\
\hline $\mathrm{Al}_{2} \mathrm{O}_{3}$ & $10-12$ & Su emme, \% & $42-50$ \\
\hline $\mathrm{Fe}_{2} \mathrm{O}_{3}$ & $0.7-1.9$ & Aşınma, mg/100g & 87 \\
\hline $\mathrm{CaO}$ & $2.4-3.7$ & Yüzey alan $1, \mathrm{~m}^{2} / \mathrm{g}$ & 39 \\
\hline $\mathrm{MgO}$ & $0.9-1.2$ & $\mathrm{pH}$ & $7-8$ \\
\hline $\mathrm{K}_{2} \mathrm{O}$ & $2.5-3.8$ & Erime, ${ }^{\circ} \mathrm{C}$ & 1300 \\
\hline LOI & $9-14$ & Yoğunluk, $\mathrm{kg} / \mathrm{dm}^{3}$ & $2.2-2.4$ \\
\hline
\end{tabular}

Limak Trakya Çimento Fabrikası'na ait TSE EN 196-1'e uygun olan Rilem Cembureau standart kumu harç numune üretiminde kullanılmıştır. Yeğenler Kimya firmasından temin edilen anataz $\mathrm{TiO}_{2}$ ve Tronox firmasından temin edilen rutil $\mathrm{TiO}_{2}$ kullanılmıştır. Tablo 4'te $\mathrm{TiO}_{2}$ 'lerin özelikleri gösterilmiştir. 
Tablo 4. Kullanılan $\mathrm{TiO}_{2}$ özelikleri

\begin{tabular}{lcccc}
\hline $\mathrm{TiO}_{2}$ & İçerik, \% & Özgül ağırlık & Tanecik boyutu, $\mu \mathrm{m}$ & Yap1 \\
\hline Anataz & 100 & 4.26 & 0.15 & toz \\
Rutil & 95 & 4.1 & 0.19 & toz \\
\hline
\end{tabular}

Hürkimsa firmasından temin edilen \% 16'l1k antibakteriyel çözelti (mergal K14) ve Biomaster firmasından temin edilen antibakteriyel toz kullanılmıştır. Tablo 5 'te antibakteriyel katkıların özelikleri gösterilmiştir.

Tablo 5. Kullanılan antibakteriyellerin özelikleri

\begin{tabular}{lcccc}
\hline & Etken madde & Yoğunluk, $\mathrm{kg} / \mathrm{dm}^{3}$ & $\mathrm{pH}$ & Yap1 \\
\hline Biomaster & Gümüş & 10.5 & 7 & beyaz toz \\
Mergal K14 & İzotiazolin & 1.02 & $3-5$ & berrak, kehribar rengi sarı s1v1 \\
\hline
\end{tabular}

Harç üretiminde bağlayıcı, su, standart kum oranları sırası ile 1, 0.5 ve 3 olarak kullanılmıştır. Titanyum dioksit $\% 0$ ve $\% 5$ oranlarında beyaz çimento ile üretilen harçlarda anataz fazında, normal Portland çimentosu ile üretilen harçlarda rutil fazında kullanılmıştır. Rutil pigmentleri yüksek kararlılık ve yüksek opaklık nedeni ile genellikle anataza tercih edilir. Ancak anataz kendini temizlemede daha çok tercih edilir [14].

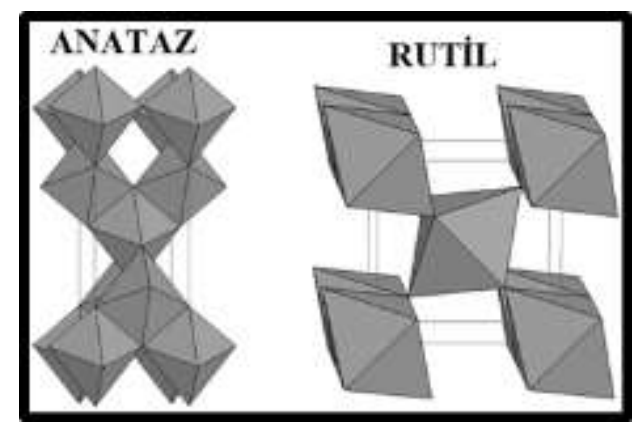

Şekil 3. Titanyum dioksitin fazları

Zeolit ise $\% 0, \% 10$ ve $\% 20$ oranlarında çimento yerine kullanılmıştır. Beyaz çimento kullanılarak üretilen harçlarda gümüş etken maddeli antibakteriyel katk1 $\% 0$ ve $\% 0.4$ oranında kullanılırken, normal Portland çimentosu ile üretilen harçlarda izotiazolin etken maddeli antibakteriyel katk1 \%0, \%0.2, \%0.4 ve \%0.6 oranında kullanılmıştır. Kullanılan malzemeler ve üretim Şekil 4'te gösterilmektedir. Üretilen harçlarda $4 \times 4 \times 16 \mathrm{~cm}$ boyutlarında prizmatik numuneler alınmış ve standart küre tabi tutulmuştur.

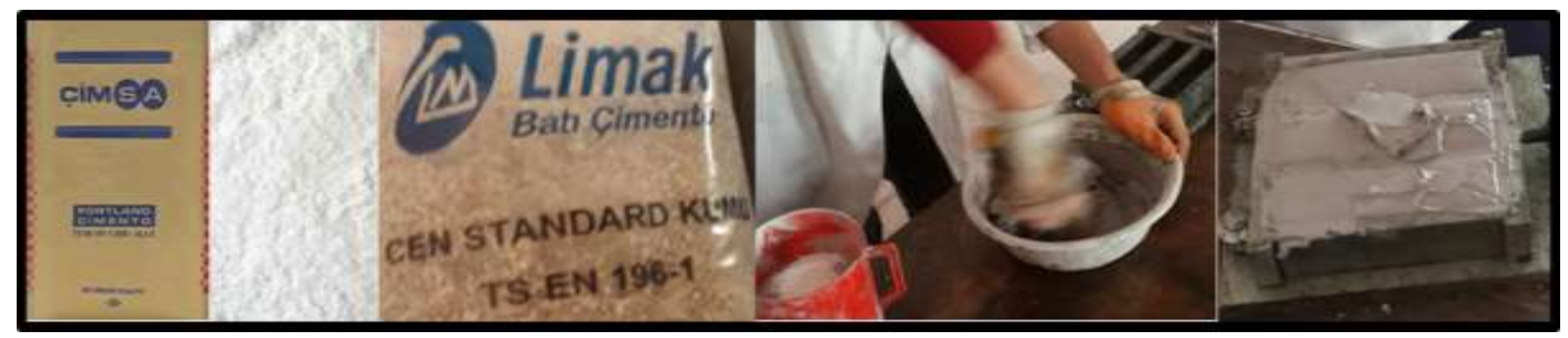

Şekil 4. Kullanılan malzemeler ve üretim

Üretimden 28 gün sonra kür havuzundan çıkarılarak Şekil 5'te gösterilen birim ağırlıkları, ultrases geçiş, eğilme ve basınç deneyleri yapılmıştır. Hesaplanan birim ağırlık, ultrases geçiş hızı, eğilme ve basınç dayanımları dikkate alınarak karışımda kullanılan zeolit, kendi kendini temizleme amaçlı kullanılan $\mathrm{TiO}_{2}$ ve antibakteriyel katkıların harcın fiziksel ve mekanik özeliklere etkisi incelenmiştir. 

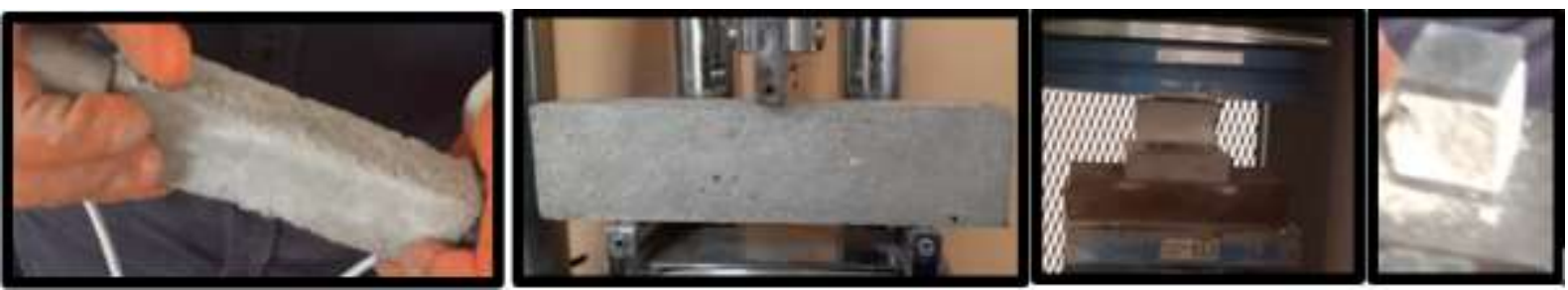

Şekil 5. Numuneler üzerinde yapılan fiziksel ve mekanik özellik deneyleri

Kendi kendini temizleme deneyleri (fotokataliz deneyleri) ile ilgili ulusal standardımız olmadığ için uluslararası düzeyde bilimsel çalışmalarda kullanılan İtalyan standartları dikkate alınmıştır (UNI 11247:2010, UNI 11259:2008). Bu standarda göre fotokatalitik aktivite tespiti için kirletici madde olarak Rhodomine-B boyar maddesi kullanılmıştır. Bu amaçla $0.05 \mathrm{~g} / \mathrm{dm}^{3}$ derişiminde Rhodomine-B çözeltisi hazırlanmıştır. Bu çözelti harç numunelerinin bir yüzü üzerinde oluşturulan $4 \times 7 \mathrm{~cm}^{2}$ bir alana $0.5 \mathrm{~cm}^{3}$ Rhodomine-B çözeltisi sürülmüsstür. Numune üzerindeki Rhodomine-B boyar maddesinin karanlık laboratuvar ortamında $\left(20^{\circ} \mathrm{C}\right.$ ve $\% 50$ bağ $\left.1 \mathrm{lnem}\right)$ kurumaya bırakılmıştır. 24 saat bekletildikten sonra ilk renk ölçümleri yapılmıştır. Renk değerlerinin okunmasında Şekil 6'da gösterilen renk ölçüm cihazı kullanılmıştır. Her ölçüm en az üç farklı noktadan kolorimetrik okumalar yapılarak ortalamaları alınmıştır. Bu okumada renk değerleri $\mathrm{L}, \mathrm{a}, \mathrm{b}, \mathrm{c}, \mathrm{h}$ şeklinde değerlendirilmiştir. Burada a: kırmızı ve mor, b: mavi ve sarı, L:siyah ve beyaz (parlaklık ve aydınlık) göstermektedir. c ve h değerleri ise renklerin renk küresi içindeki derinlikleri belirlemektedir.
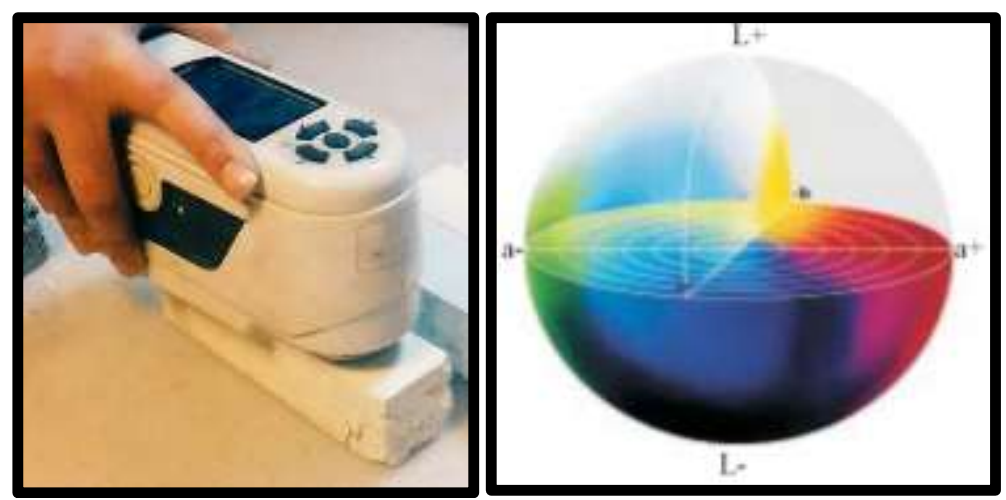

Şekil 6. Renk kartelası ve renk ölçümü

İlk renk ölçümü değerleri alındıktan sonra numuneler karanlık ortamda UV 1şık kaynağına yaklaşık $75 \mathrm{~cm}$ uzaklıkta olacak şekilde dizilmiştir. UV 1şık kaynağı olarak 300 watt Osram marka gücünde ampül kullanılmıştır. Şekil 7'de kendi kendini temizleme deney uygulaması görülmektedir. Numuneler UV ışık kaynağı altında 26 saat bekletildikten sonra 26 saatlik kolorimetrik okumaları yapılmıştır. Daha sonra numuneler 240 saat boyunca tekrar UV 1şığa maruz bırakılmıştır. Bu süre sonrasında renk ölçüm cihazı kullanılarak 240 saatlik son kolorimetrik okumalar yapılmıştır. $\mathrm{Bu}$ deneyde Rhodamine-B boyar maddesi kullanıldığ için burada etken kolorimetrik okuma değeri olarak kırmızı-mor renk değişimini gösteren a değeri dikkate alınmıştır. Kendi kendini temizleme sonrasındaki renk açılmalarının hesabında ilk okunan a değerinden $\left(\mathrm{a}_{(0)}\right)$ UV ışık kaynağında 26 ve 240 saat bekletildikten sonra ölçülen a değerleri $\left(\mathrm{a}_{(26)}, \mathrm{a}_{(\text {(son) }}\right)$ ayrı ayrı çıkartılmıştır. Daha sonra ilk okunan a değerine $\left(\mathrm{a}_{(0)}\right)$ bölünmüştür. Elde edilen değerlerin yüzdesi alınarak görece renk değişimi $\left(\mathrm{R}_{26}, \mathrm{R}_{\text {son }}\right)$ hesaplanmıştır. Karışımlarda kullanılan anataz ve rutil fazındaki $\mathrm{TiO}_{2}$ 'in beton, harç ve derz numunelerinin kendi kendini temizlemedeki etkinliği renk açılmaları dikkate alınarak İtalyan standartlarına göre incelenmiştir. 

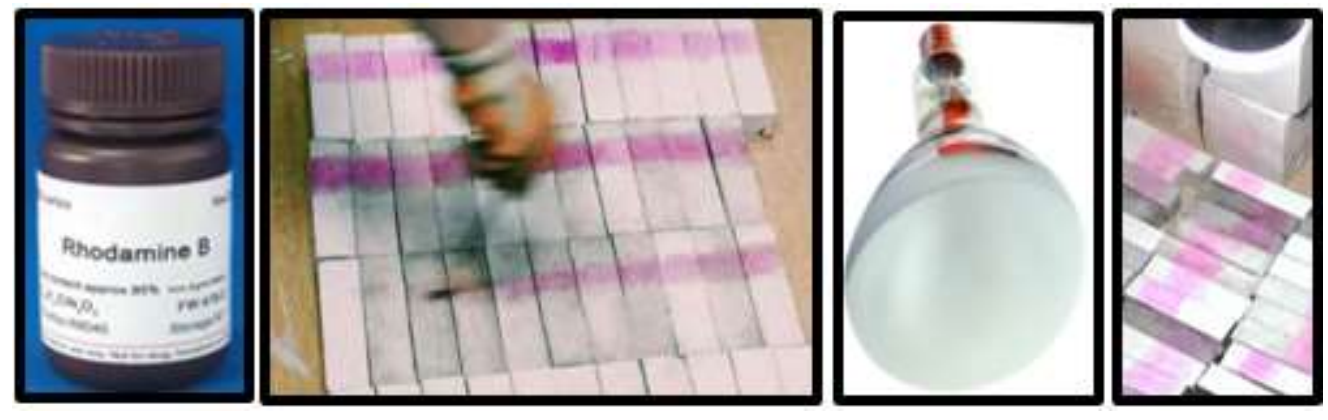

Şekil 7. Numuneler üzerinde yapılan fiziksel ve mekanik özellik deneyleri

Yüzeylerin antibakteriyel etkinlikleri, ASTM E2149 test yöntemine göre sayısal olarak test edilmiştir. Çalışma sırasında, Gram-pozitif bakteri suşu olarak Staphylococcus aureus (ATCC 6538) ve Gram-negatif bakteri suşu olarak Escherichia coli (ATCC 35218) seçilmiştir. Numunelere, 1.5-3x105 $\mathrm{cfu} / \mathrm{mL}$ yoğunlukta bakteri çözeltisi aktarılmış, $37^{\circ} \mathrm{C}$ 'de 150 devir/dakika çalkalama hızında 24 saat süre ile inkübe edildikten sonra seri sulandırmalar yapılarak besiyerlerine ekimler yapılmış ve antibakteriyel etkinlik değeri bulunmuştur. Karışımlarda kullanılan gümüş ve izotiazolin etken maddeli antibakteriyel katkının harç numunelerinin antibakteriyel etkinliği bulunan etkinlik değerleri dikkate alınarak incelenmiştir.

\section{Bulgular ve Tartışma}

Harç numune üzerinde yapılan fiziksel ve mekanik deneylerin sonuçları Tablo 6'da verilmiştir. Çalışmamızın amacı kullanılan katkıların sertleşmiş harç özeliklerine bu katkıların herhangi bir olumsuz etkisi olup olmadığı belirlenmiştir. Burada miktar olarak en çok kullanılan katkı zeolit olduğu için zeolitin etkisi üzerinde daha çok durulmuştur. Tablo 6 incelendiğinde zeolit, titanyum dioksit ve antibakteriyel katkının harcın birim ağırlık, ultrases geçiş hızı, eğilme ve basınç dayanımı gibi özeliklerini dikkate değer ölçüde değiştirmediği görülmüştür.

Tablo 6. Normal Portland çimentosu ile üretilen harç numunelerin fiziksel ve mekanik özelikleri

\begin{tabular}{|c|c|c|c|c|}
\hline & $\begin{array}{c}\text { Birim ağırlık, } \\
\mathrm{kg} / \mathrm{dm}^{3}\end{array}$ & $\begin{array}{c}\text { Ultrases geçiş hızı, } \\
\mathrm{m} / \mathrm{sn}\end{array}$ & $\begin{array}{c}\text { Eğilme Dayanımı, } \\
\text { MPa }\end{array}$ & $\begin{array}{c}\text { Basınç Dayanımı, } \\
\text { MPa }\end{array}$ \\
\hline$\% 0 \mathrm{Z}+\% 0 \mathrm{~A}+\% 0 \mathrm{~T}$ & 2.191 & 3.791 & 1.875 & 19.828 \\
\hline$\% 0 \mathrm{Z}+\% 0.2 \mathrm{~A}+\% 0 \mathrm{~T}$ & 2.258 & 3.544 & 2.227 & 24.469 \\
\hline$\% 0 \mathrm{Z}+\% 0.4 \mathrm{~A}+\% 0 \mathrm{~T}$ & 2.195 & 3.604 & 2.227 & 20.141 \\
\hline$\% 0 \mathrm{Z}+\% 0.6 \mathrm{~A}+\% 0 \mathrm{~T}$ & 2.063 & 3.524 & 2.461 & 19.859 \\
\hline$\% 0 \mathrm{Z}+\% 0 \mathrm{~A}+\% 5 \mathrm{~T}$ & 2.221 & 3.712 & 2.930 & 26.156 \\
\hline$\% 0 \mathrm{Z}+\% 0.2 \mathrm{~A}+\% 5 \mathrm{~T}$ & 2.203 & 3.678 & 2.109 & 22.484 \\
\hline$\% 0 \mathrm{Z}+\% 0.4 \mathrm{~A}+\% 5 \mathrm{~T}$ & 2.309 & 3.678 & 2.578 & 22.750 \\
\hline$\% 0 \mathrm{Z}+\% 0.6 \mathrm{~A}+\% 5 \mathrm{~T}$ & 2.090 & 3.632 & 2.695 & 19.328 \\
\hline$\% 10 \mathrm{Z}+\% 0 \mathrm{~A}+\% 0 \mathrm{~T}$ & 2.203 & 3.687 & 2.109 & 21.766 \\
\hline$\% 10 \mathrm{Z}+\% 0.2 \mathrm{~A}+\% 0 \mathrm{~T}$ & 2.191 & 3.712 & 2.578 & 29.625 \\
\hline$\% 10 \mathrm{Z}+\% 0.4 \mathrm{~A}+\% 0 \mathrm{~T}$ & 2.230 & 3.645 & 2.578 & 21.969 \\
\hline$\% 10 \mathrm{Z}+\% 0.6 \mathrm{~A}+\% 0 \mathrm{~T}$ & 2.211 & 3.712 & 2.578 & 24.703 \\
\hline$\% 10 \mathrm{Z}+\% 0 \mathrm{~A}+\% 5 \mathrm{~T}$ & 2.246 & 3.704 & 2.695 & 26.203 \\
\hline$\% 10 \mathrm{Z}+\% 0.2 \mathrm{~A}+\% 5 \mathrm{~T}$ & 2.232 & 3.810 & 2.695 & 22.297 \\
\hline$\% 10 \mathrm{Z}+\% 0.4 \mathrm{~A}+\% 5 \mathrm{~T}$ & 2.227 & 3.751 & 2.813 & 27.203 \\
\hline$\% 10 \mathrm{Z}+\% 0.6 \mathrm{~A}+\% 5 \mathrm{~T}$ & 2.012 & 3.249 & 1.758 & 18.563 \\
\hline$\% 20 \mathrm{Z}+\% 0 \mathrm{~A}+\% 0 \mathrm{~T}$ & 2.172 & 3.769 & 2.813 & 27.656 \\
\hline$\% 20 \mathrm{Z}+\% 0.2 \mathrm{~A}+\% 0 \mathrm{~T}$ & 2.160 & 3.563 & 2.227 & 21.516 \\
\hline$\% 20 \mathrm{Z}+\% 0.4 \mathrm{~A}+\% 0 \mathrm{~T}$ & 2.203 & 3.751 & 2.461 & 19.125 \\
\hline$\% 20 \mathrm{Z}+\% 0.6 \mathrm{~A}+\% 0 \mathrm{~T}$ & 2.250 & 3.661 & 2.578 & 17.875 \\
\hline$\% 20 \mathrm{Z}+\% 0 \mathrm{~A}+\% 5 \mathrm{~T}$ & 2.203 & 3.869 & 2.578 & 22.344 \\
\hline$\% 20 \mathrm{Z}+\% 0.2 \mathrm{~A}+\% 5 \mathrm{~T}$ & 2.293 & 3.687 & 2.695 & 24.813 \\
\hline$\% 20 \mathrm{Z}+\% 0.4 \mathrm{~A}+\% 5 \mathrm{~T}$ & 2.109 & 3.842 & 2.344 & 17.734 \\
\hline$\% 20 \mathrm{Z}+\% 0.6 \mathrm{~A}+\% 5 \mathrm{~T}$ & 2.109 & 3.778 & 2.461 & 20.875 \\
\hline
\end{tabular}


Tablo 7'de beyaz çimento ile üretilen harçların özelikleri gösterilmiştir. Tablo 7 incelendiğinde birim ağırlıkların 2.1 ile $2.2 \mathrm{~kg} / \mathrm{dm}^{3}$ arasında değiştiği, ultrases geçiş hızlarının 3.4 ile $3.8 \mathrm{~m} / \mathrm{sn}$ arasında değiştiği, eğilme dayanımlarının 1.6 ile $2.7 \mathrm{MPa}$ arasında değiştiği, basınç dayanımlarının 19 ile $31 \mathrm{MPa}$ arasında değiştiği görülmüştür. En yüksek dayanım $30.7 \mathrm{MPa}$ ile \% 20 zeolit, \% 5 titanyum dioksit ve $\% 0.4$ antibakteriyel katkı kullanılan numunelerde görülürken, en düşük dayanım $19.5 \mathrm{MPa}$ ile sadece \% 5 titanyum dioksit kullanılan numunelerde görülmüştür. Titanyum dioksit kullanımı ile basınç dayanımları \% 5, zeolit kullanımı ile \% 16'ya ulaşan oranlarda artmıştır.

Tablo 7. Beyaz çimento ile üretilen harç numunelerin fiziksel ve mekanik özelikleri

\begin{tabular}{ccccc}
\hline & $\begin{array}{c}\text { Birim ağırlık, Ultrases geçiş hızı, Eğilme Dayanımı, Basıç Dayanımı, } \\
\mathrm{kg} / \mathrm{dm}^{3}\end{array}$ & $\mathrm{~m} / \mathrm{sn}$ & $\mathrm{MPa}$ & $\mathrm{MPa}$ \\
\hline$\% 0 \mathrm{Z}+\% 0.4 \mathrm{~A}+\% 0 \mathrm{~T}$ & 2.203 & 3.653 & 2.344 & 28.266 \\
$\% 0 \mathrm{Z}+\% 0 \mathrm{~A}+\% 0 \mathrm{~T}$ & 2.109 & 3.437 & 2.695 & 21.250 \\
$\% 0 \mathrm{Z}+\% 0.4 \mathrm{~A}+\% 5 \mathrm{~T}$ & 2.188 & 3.760 & 1.992 & 25.828 \\
$\% 0 \mathrm{Z}+\% 0 \mathrm{~A}+\% 5 \mathrm{~T}$ & 2.133 & 3.730 & 1.875 & 19.484 \\
$\% 10 \mathrm{Z}+\% 0.4 \mathrm{~A}+\% 0 \mathrm{~T}$ & 2.176 & 3.365 & 1.641 & 25.016 \\
$\% 10 \mathrm{Z}+\% 0 \mathrm{~A}+\% 0 \mathrm{~T}$ & 2.160 & 3.670 & 1.758 & 26.203 \\
$\% 10 \mathrm{Z}+\% 0.4 \mathrm{~A}+\% 5 \mathrm{~T}$ & 2.207 & 3.774 & 2.109 & 23.047 \\
$\% 10 \mathrm{Z}+\% 0 \mathrm{~A}+\% 5 \mathrm{~T}$ & 2.176 & 3.509 & 1.758 & 23.203 \\
$\% 20 \mathrm{Z}+\% 0.4 \mathrm{~A}+\% 0 \mathrm{~T}$ & 2.180 & 3.616 & 1.758 & 23.734 \\
$\% 20 \mathrm{Z}+\% 0 \mathrm{~A}+\% 0 \mathrm{~T}$ & 2.129 & 3.666 & 1.992 & 25.328 \\
$\% 20 \mathrm{Z}+\% 0.4 \mathrm{~A}+\% 5 \mathrm{~T}$ & 2.137 & 3.575 & 1.641 & 30.703 \\
$\% 20 \mathrm{Z}+\% 0 \mathrm{~A}+\% 5 \mathrm{~T}$ & 2.121 & 3.695 & 1.758 & 29.438 \\
\hline
\end{tabular}

Kendi kendini temizleme deneyi olarak Rhodamine-B kullanılarak yapılan renk açılması değerlerinin ölçümü ve ölçüm sonuçlarının karşılaştırmalı değerlendirilmesi yapılmıştır. Renk ölçümleri 26 saat ve 240 saat olmak üzere iki farklı zamanda UV 1şı altında bekleyen numuneler üzerinden yapılmıştır. Anataz fazında titanyum dioksit kullanılan ve kullanılmayan beyaz çimento ile üretilen harç numunelerin 26 saat UV kaynağı altındaki renk açılmaları ve 240 saat UV kaynağı altındaki renk açılmaları Şekil 8'de gösterilmiştir. Şekil 8 incelendiğinde renk açılmalarının \%55'e yaklaşan oranlara ulaştı̆̆ 1 , titanyum dioksit kullanılması durumunda renk açılmasını \%40'a ulaşan oranlarda arttırdığ görülmüştür. UV kaynağı altındaki bekleme süresi 240 saate ulaştığında renk açılmaları \%93'e ulaşırken, titanyum dioksit ilavesi renk açılmalarını \%50'ye ulaşan oranda arttırdığı belirlenmiştir.
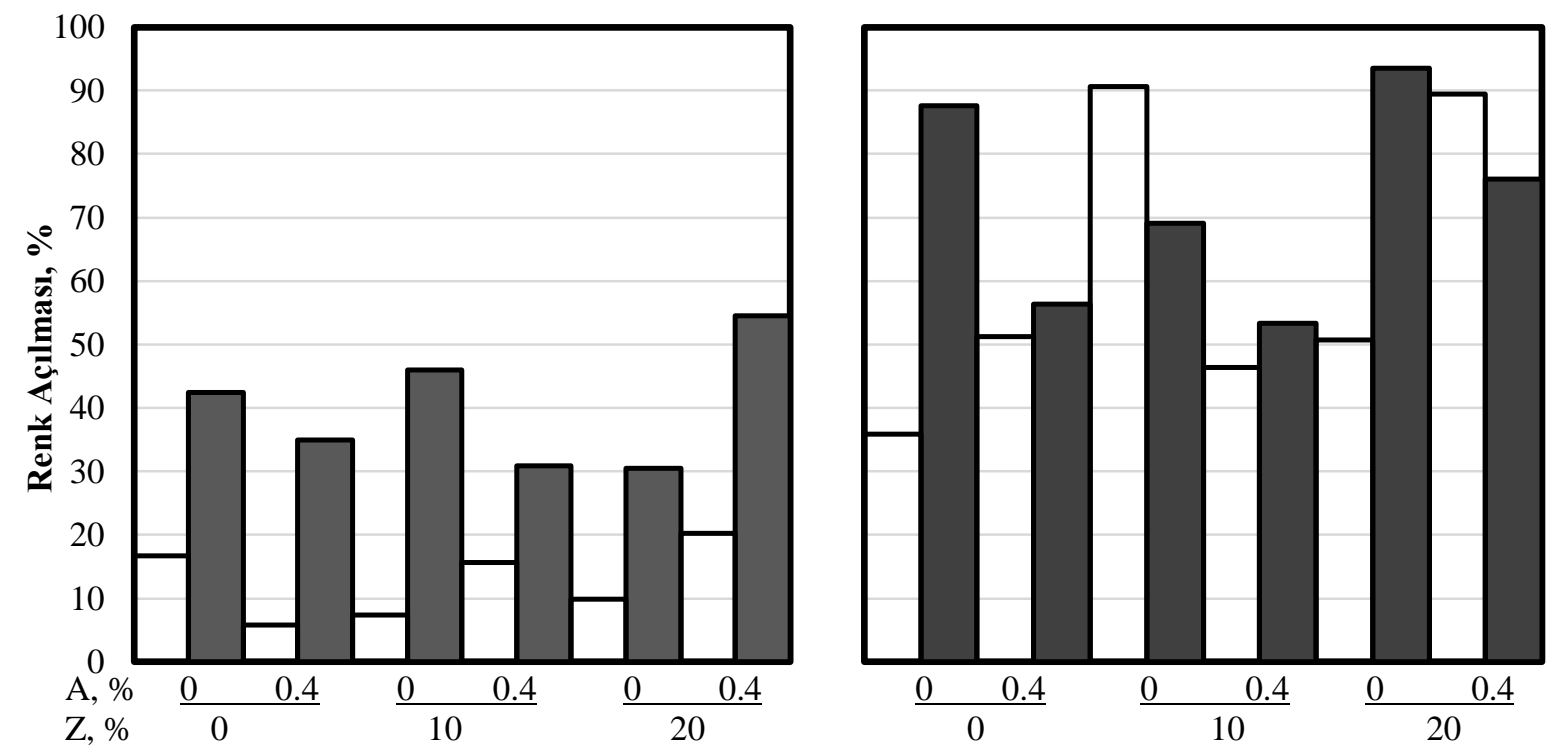

Şekil 8. Beyaz çimento ile üretilen harç numunelerin renk açılmaları 


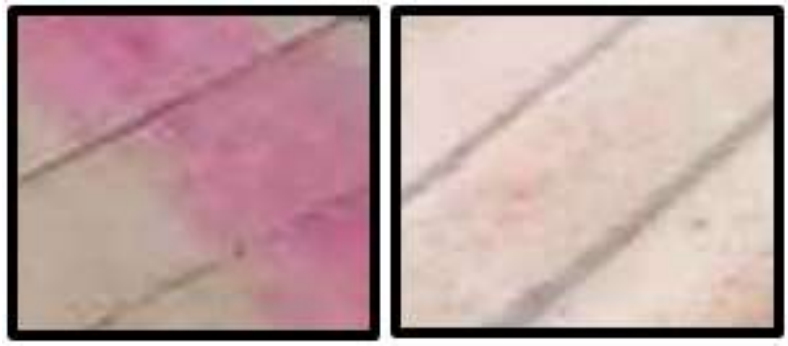

Şekil 9. Rhodamine-B ile yapılan çalışmada UV ışık altında meydana gelen renk açılması

Harç numunelerin fotokataliz sonucu meydana gelen renk açılması Şekil 9'da gösterilmektedir. Fotokataliz sonucu titanyum dioksit ile kendi kendini temizleme yeteneğinin kazanıldığı görülmüştür. Harç numunelerin 26 saat UV kaynağı altındaki renk açılmaları ve 240 saat UV kaynağı altındaki renk açılmaları Şekil 10'da gösterilmiştir. Şekil 10 incelendiğinde rutil fazında titanyum dioksit kullanılmasının özelikle zeolit katılmış numunelerin renk açılmalarını $\% 25$ 'e ulaşan oranlarda arttırdığ görülmüştür. Işık kaynağı altındaki bekleme süresi 240 saate ulaştı̆̆ında renk açılmalarının \%80 mertebesine yükseldiği gözlenmiştir. Zeolit ilavesi genel olarak değişkenlik gösterse de \%50'ye ulaşan oranlarda renk açılmalarını arttırmıştır.
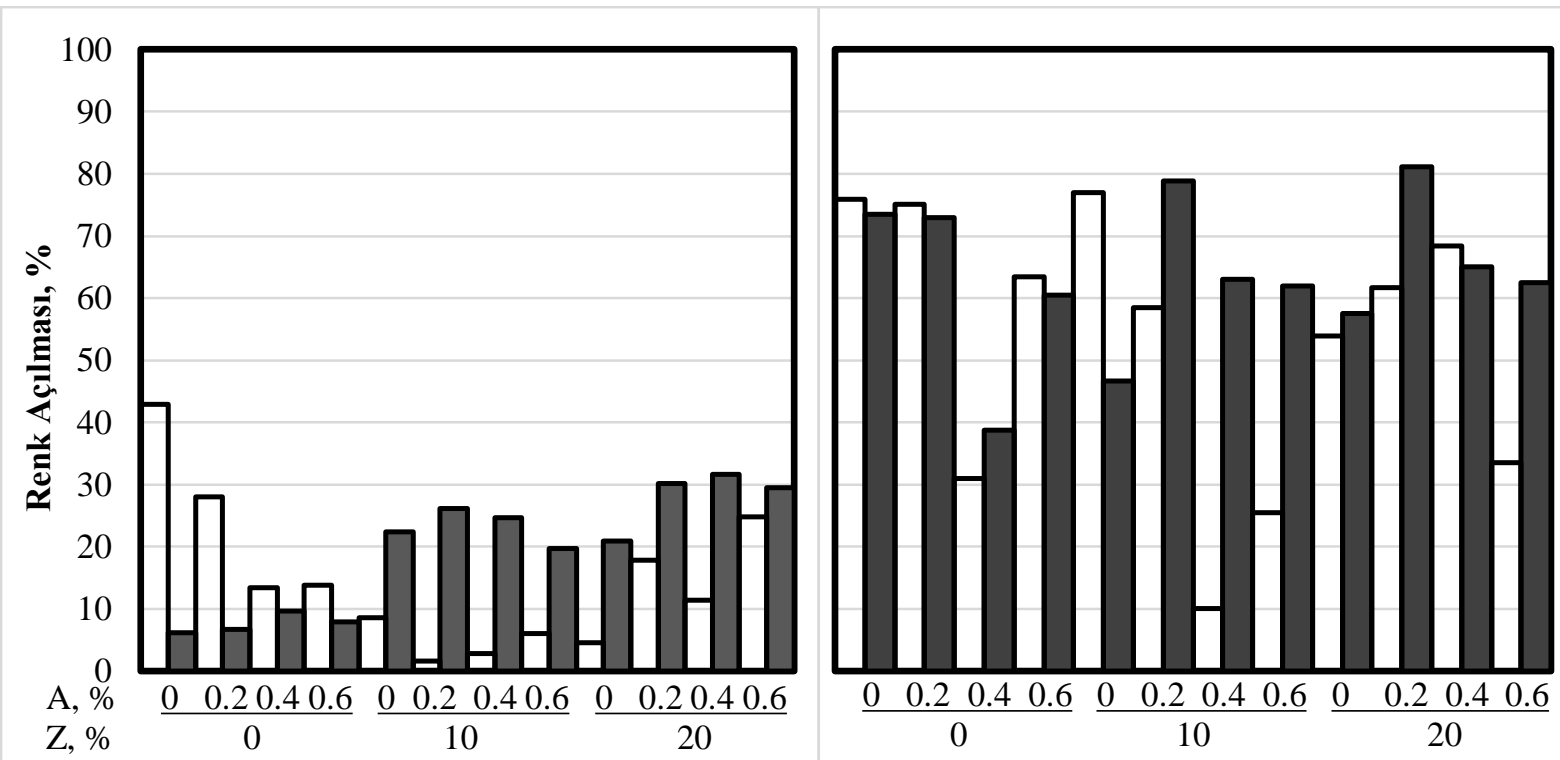

Şekil 10. Normal Portland çimentosu ile üretilen harç numunelerin 26 saatlik renk açılmaları

Tablo 8'de harç numunelerin antibakteriyel etkinlik değerleri verilmektedir. Tablo 8 incelendiğinde harç numunelerinin Staphylococcus aureus bakterisine karş1 etkili olduğu görülürken, Escherichia coli bakterisine karşı harç üretiminde antibakteriyel katkı kullanılması gerektiği görülmüştür.

Staphylococcus aureus ve Escherichia coli bakterilerinin mikrografları, oluşturdukları koloniler ve desenleri (patern) Şekil 11'de görülmektedir[15]. Gümüşün antibakteriyel özelliğinin sadece mikroorganizmaların gümüşü adsorbe etmelerinden kaynaklanmadığını aynı zamanda gümüş iyonunun çözelti içinde serbestçe dolaşmadığı ve inorganik bir bileşik içine yerleştirildiği durumlarda da mikroorganizmaların gümüşü adsorbe etmeden de kolonileşme ve çoğalma özelliklerini yitirdiklerini gözlemişlerdir. Bu nedenle Şekil 12'den de görüldüğü gibi gümüş iyonlarını sabitlemek için iyon değiştirme özelliğine sahip malzemeler olan zeolitlerin kullanılabileceği gözlenmiştir[16]. 
Tablo 8 Harç numunelerin antibakteriyel etkinlik değerleri

\begin{tabular}{|c|c|c|c|c|c|c|c|c|}
\hline & \multicolumn{4}{|c|}{ Beyaz çimento } & \multicolumn{4}{|c|}{ Normal Portland çimentosu } \\
\hline & \multicolumn{2}{|c|}{$\begin{array}{c}\text { S. aureus } \\
(\text { ATCC 6538) }\end{array}$} & \multicolumn{2}{|c|}{$\begin{array}{c}\text { E. coli } \\
\left(\text { (ATCC 35218) }^{\mathrm{b}}\right.\end{array}$} & \multicolumn{2}{|c|}{$\begin{array}{c}\text { S. aureus } \\
\left(\text { (ATCC 6538) }^{\mathrm{a}}\right.\end{array}$} & \multicolumn{2}{|c|}{$\begin{array}{c}\text { E. coli } \\
(\text { ATCC 35218) }\end{array}$} \\
\hline & $\%$ & $\log$ & $\%$ & $\log$ & $\%$ & $\log$ & $\%$ & $\log$ \\
\hline Kontrol & -81.25 & -0.73 & -2.44 & -0.01 & -81.25 & -0.73 & -2.44 & -0.01 \\
\hline$\% 0 \mathrm{Z}+\% 0 \mathrm{~A}+\%$ & 00.00 & -6.30 & -100.00 & -5.67 & 100.00 & -6.30 & -100.00 & -5.67 \\
\hline$\% 0 \mathrm{Z}+\% 0.4 \mathrm{~A}+\% 0 \mathrm{~T}$ & -100.00 & -6.30 & -100.00 & -5.67 & -100.00 & -6.30 & -100.00 & -5.67 \\
\hline$\% 0 \mathrm{Z}+\% 0 \mathrm{~A}+\% 5 \mathrm{~T}$ & -100.00 & -6.30 & 7.32 & 0.03 & -100.00 & -6.30 & -100.00 & -5.67 \\
\hline$\% 0 \mathrm{Z}+\% 0.4 \mathrm{~A}+\% 5 \mathrm{~T}$ & -100.00 & -6.30 & -100.00 & -5.67 & -100.00 & -6.30 & -100.00 & -5.67 \\
\hline$\% 10 \mathrm{Z}+\% 0$ & -100.00 & -6.30 & -100.00 & -5.67 & -100.00 & -6.30 & -100.00 & -5.67 \\
\hline$\% 10 \mathrm{Z}+\% 0.4 \mathrm{~A}+\% 0 \mathrm{~T}$ & -100.00 & -6.30 & -100.00 & -5.67 & -100.00 & -6.30 & -100.00 & -5.67 \\
\hline$\% 10 \mathrm{Z}+\% 0 \mathrm{~A}+\% 5 \mathrm{~T}$ & -100.00 & -6.30 & -100.00 & -5.67 & -100.00 & -6.30 & 34.15 & 0.13 \\
\hline$\% 10 \mathrm{Z}+\% 0.4 \mathrm{~A}+\% 5 \mathrm{~T}$ & -100.00 & -6.30 & -100.00 & -5.67 & -100.00 & -6.30 & -89.07 & -0.96 \\
\hline$\% 20 \mathrm{Z}+\% 0 \mathrm{~A}+\% 0 \mathrm{~T}$ & -100.00 & -6.30 & 124.39 & 0.35 & -100.00 & -6.30 & -98.93 & -1.97 \\
\hline$\% 20 \mathrm{Z}+\% 0.4 \mathrm{~A}+\% 0 \mathrm{~T}$ & -100.00 & -6.30 & -100.00 & -5.67 & -100.00 & -6.30 & -100.00 & -5.67 \\
\hline$\% 20 \mathrm{Z}+\% 0 \mathrm{~A}+\% 5 \mathrm{~T}$ & -100.00 & -6.30 & -98.71 & -1.89 & -100.00 & -4.64 & -100.00 & -5.67 \\
\hline$\% 20 \mathrm{Z}+\% 0.4 \mathrm{~A}+\% 5 \mathrm{~T}$ & -100.00 & -6.30 & -100.00 & -5.67 & -100.00 & -4.34 & -100.00 & -5.67 \\
\hline
\end{tabular}

${ }^{a}$ Her bir örneğe aktarılan bakteri konsantrasyonu, 2,00 x $10^{6}(\log 6,30) \mathrm{cfu} * / \mathrm{mL}$ olarak hesaplanmıştır.

${ }^{b}$ Her bir örneğe aktarılan bakteri konsantrasyonu, 4,66 x $10^{5}(\log 5,67) \mathrm{cfu} * / \mathrm{mL}$ olarak hesaplanmıştır.

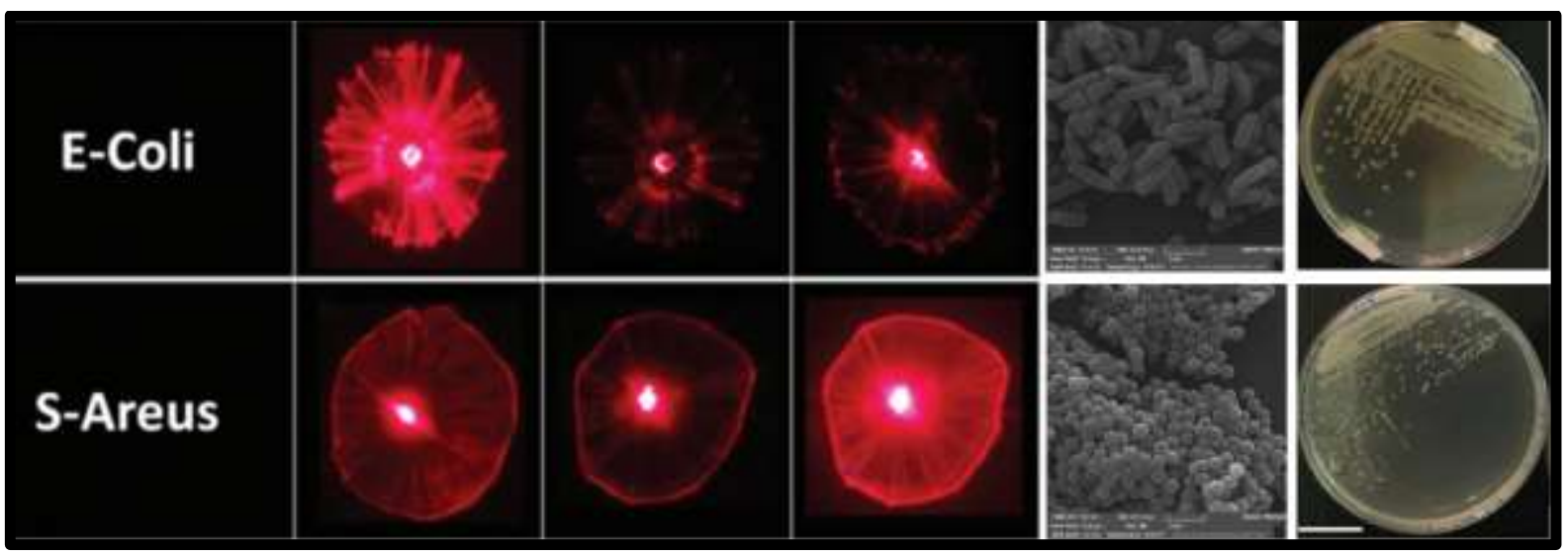

Şekil 11. Bakterilerin kolonileşmesi

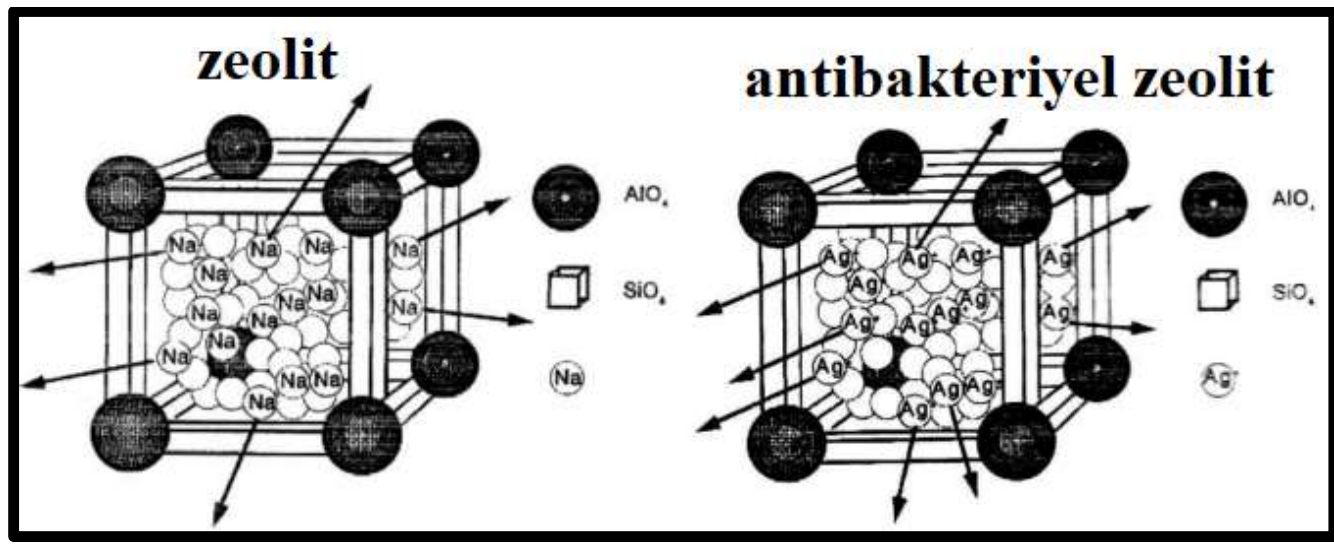

Şekil 12. Antibakteriyel etkinlikte zeolitin rolü

\section{Sonuç ve Öneriler}

Yapılan çalışmalar sonucunda fiziksel ve mekanik açıdan değerlendirildiğinde harç numuneler üzerinde yapılan katkıların dikkate değer ölçüde özellikleri değiştirmediği, derz numuneler üzerinde yüksek zeolit kullanımın dayanımları olumsuz etkilediği, katkılı ve katkısız beton numuneleri üzerinde ise kullanılan katkıların birim ağırlık ve ultrases geçiş hızlarını dikkate değer ölçüde etkilemediği görülürken, basınç dayanımlarını ise düzensiz olarak değiştirdiği görülmüştür. 
Kolorimetrik okuma sonuçları değerlendirildiğinde tüm numuneler üzerinde $\mathrm{TiO}_{2}$ ve zeolit kullanımın UV ışık kaynağı altında zamanla oluşan renk açılması yönünden olumlu etkisinin bulunduğu görülmüştür. Titanyumdioksit kullanımının \%70'e yaklaşan oranlarda renk açılmasına sebep olduğu, ancak \%20 oranında zeolit kullanımının genel renk açılmasını arttırdığ 1 ancak titanyum dioksitin temizleme etkisinin düzenli olmadığı görülmüştür. UV kaynağı altındaki bekleme süresi arttığında titanyum dioksitin fotokataliz etkisinin belirginleştiği ve zeolit ilavesi renk açılmalarına olumlu katkısının olduğu belirlenmiştir.

Antibakteriyel aktivitenin incelenmesi konusunda ise zeolit ilavesi bulunan derz, harç ve beyaz çimento ile üretilen beton numuneleri üzerinde zeolitin Staphylococcus Aureus bakterisine karşı etkili olduğu görülürken, Escherichia coli bakterisine karşı antibakteriyel katkı kullanılması gerektiği görülmüştür. Normal Portland çimentosu ile üretilen beton numuneleri ise zeolit ilavesinin hem Staphylococcus aureus bakterisine hem de Escherichia coli bakterisine karşı etkili olduğu görülmüştür.

\section{Teşekkür}

$\mathrm{Bu}$ çalışma Eskişehir Osmangazi Üniversitesi Bilimsel Araştırma Projeleri Koordinasyon Birimi tarafindan "201715D45” nolu proje kapsamında desteklenmiştir

\section{Yazarların Katkısı}

Yazarlar makaleye eşit katkı derecede katkı sağlamıştır.

\section{Çıkar Çatışması Beyanı}

Yazarlar arasında herhangi bir çıkar çatışması bulunmamaktadır.

\section{Araştırma ve Yayın Etiği Beyanı}

Yapılan çalışmada araştırma ve yayın etiğine uyulmuştur.

\section{Kaynaklar}

[1] Akdur R., Çöl M., Işık A., İdil A., Durmuşoğlu M., Tunçbilek A. 1998. Halk sağlı̆̆ı. Antıp AŞ Tip Kitapları ve Bilimsel Yayınlar, No:26, 53

[2] Doğan A., Pekşen C. 2005. Metal İyon Katk1lı Antimikrobiyal Malzemelerin Hastane İnfeksiyonlarını Önlemede Katkıları ve Uygulamaları. 4. Ulusal Sterilizasyon Dezenfeksiyon Kongresi kitab1, Samsun, 20-24

[3] Ozga I., Bonazza, A., Bernardi, E., Tittarelli, F., Favoni, O., Ghedini, N., Morselli, L. \& Sabbioni, C. 2011. Diagnosis of Surface Damage Induced by Air Pollution On 20th-Century Concrete Buildings. Atmospheric Environment, 45(28): 4986-4995.

[4] Krishnan P., Zhang M.H., Yu L., Feng H. 2013. Photocatalytic Degradation of Particulate Pollutants and Self-Cleaning Performance of $\mathrm{TiO}_{2}$-Containing Silicate Coating and Mortar. Construction and Building Materials, 44: 309-316.

[5] Nakata K., Ochiai T., Murakami T., Fujishima A. 2012. Photoenergy Conversation with $\mathrm{TiO}_{2}$ Photocatalysis: New materials and Recent Applications. Electrochimica Acta, 84: 103-111.

[6] Ni M., Leung M.K., Leung D.Y., Sumathy K. 2007. A Review and Recent Developments in Photocatalytic Water-Splitting Using $\mathrm{TiO}_{2}$ for Hdrogen Production. Renewable and Sustainable Energy Reviews, 11(3): 401-425.

[7] Canbaz M., Ünverdi H.T., Balk Y. 2015. Kendi Kendini Temizleyen Derz Dolgu Malzemeleri. Uludağ Üniversitesi Mühendislik Fakültesi Dergisi, 21(1): 13-24.

[8] Orhon A.V. 2014. Kendini Temizleyen Cephe Sistemleri. 7. Ulusal Çatı \& Cephe Sempozyumu, 3-4 Nisan, İstanbul, 9.

[9] Gülen J., Zorbay F., Arslan S. 2012. Zeolitler ve kullanım alanları. Karaelmas Fen ve Mühendislik Dergisi, 2(1): 63-68. 
[10] Can C., Körlü A., Ateş M. 2013. Gümüş Yüklü Zeolitlerin Pamuklu Kumaşların Antibakteriyel Bitim İşleminde Kullanımı. Tekstil ve Konfeksiyon, 23(1): 32-36.

[11] Harımdar N., Akarslan F. 2020. Pamuklu Kumaşa Antibakteriyel Bitim Uygulaması. Avrupa Bilim ve Teknoloji Dergisi, 18: 142-147.

[12] Yüksel F.Ş.K., Karagüller M. 2011. Kendi Kendini Temizleyen Betonlar. Beton 2011 Kongresi, İstanbul, 470-480.

[13] Akalın K.B., Özmen P., Tiftikçi C., Canbaz M., Bilgiç Ş., Kara Ç. 2015. Beton Kaldırım Taşları ve Yol Kaplama Yüzeylerinde Meydana Gelen Kirliliklerin UV Güneş Işınları ile Temizlenmesi. Elektronik Mesleki Gelişim ve Araştırma Dergisi, 3(1): 150-161.

[14] Kılıçoğlu B. D. 2009. Nanoboyutlu $\mathrm{TiO}_{2}$ Esaslı Antibakteriyel Kaplama. Doktora Tezi, Yıldız Teknik Üniversitesi, Fen Bilimleri Enstitüsü, Metalürji ve Malzeme Mühendisliği Anabilim Dalı, İstanbul, 114.

[15] Sasanpour P., Dilmaghani-Marand A., Montazeri, H., Ivani S., Hajipour M.J., Mahmoudi M., 2019. Nanoparticles Affect Bacterial Colonies' Optical Diffraction Patterns. Nanoscale, 11(6): 2594-2601.

[16] Ata U. H. 2003. Antibakteriyel Klinoptilolit. Yüksek Lisans Tezi, İstanbul Teknik Üniversitesi, Fen Bilimleri Enstitüsü, Kimya Mühendisliği Anabilim Dalı, 61. 